\title{
HUBUNGAN AKTIVITAS FISIK DENGAN FUNGSI KOGNITIF LANSIA PADA LANSIA USIA 60-69 TAHUN DI KELURAHAN PURWANTORO KECAMATAN BLIMBING KOTA MALANG
}

\author{
Aqidatul Izzah \\ Fakultas Kedokteran Universitas Muhammadiyah Malang, Jl. Bendungan Sutami No. 188A, Kota Malang, \\ 65145, Indonesia, (0341) 551149 aqidatul21@gmail.com
}

\begin{abstract}
ABSTRAK
Hubungan Aktivitas Fisik dengan Fungsi Kognitif Lansia pada Lansia Usia 60-69 Tahun di Kelurahan Purwantoro Kecamatan Blimbing Kota Malang. Latar Belakang: Jumlah penduduk lanjut usia semakin meningkat dari tahun ke tahun. Pada orang lanjut usia cenderung terjadi penurunan dari fungsi kognitif. Aktivitas fisik dapat mencegah atau memperlambat onset dari penurunan fungsi kognitif. Tujuan: Mengetahui hubungan aktivitas fisik dengan fungsi kognitif lansia pada lansia. Metode: Jenis penelitian analitik observasional dengan pendekatan cross sectional. Teknik pengambilan sampel adalah consecutive sampling. Besar sampel adalah 95 orang. Dilakukan uji Chi-Square untuk menentukan hubungan antar variabel. Hasil Penelitian dan Diskusi: Didapatkan skor fungsi kognitif pada lansia dengan skor 0-23 (gangguan kognitif), sebanyak 71,4\% memiliki aktivitas fisik rendah dan sebanyak 28,6\% memiliki aktivitas fisik sedang. Sedangkan yang memiliki skor 24-30 (tidak gangguan kognitif), sebanyak 84,1\% memiliki aktivitas fisik sedang, 11,4\% memiliki aktivitas fisik berat, dan 4,5\% memiliki aktivitas fisik rendah. Hasil analisis dengan uji Chi-Square didapatkan nilai signifikansi 0.000 (lebih kecil dari $\alpha=0,05$ ). Hubungan antara aktivitas fisik dengan fungsi kognitif adalah hubungan yang positif. Kesimpulan: Terdapat hubungan antara aktivitas fisik dengan fungsi kognitif lansia. Semakin tinggi aktivitas fisik, maka akan semakin tinggi pula skor fungsi kognitifnya.
\end{abstract}

\begin{abstract}
The Correlation Between Physical Activity and Cognitive Function to Elderly Aged 60-69 Years in Purwantoro Village Blimbing Sub-District Malang City. Backeground: The number of elderly people is increasing every year. The cognitive function tend to decline in the elderly. Physical activity can prevent or delay the onset of cognitive impairment. Objective: The aim of this research was to determine the correlation between physical activity and cognitive function in the elderly. Methods: This was an analytic observational research by cross sectional approach. Consecutive sampling method was used to get samples. The sample size for this research was 95 people. The correlation between variables were carried out by Chi-Square test. Results and Discussion: The result of this research showed that cognitive function in elderly whom had score from 0-23 indicated cognitive impairment. About 5.3\% people had low physical activity and 2.1\% people had moderate physical activity. While the number of samples that had score from 24-30 indicated no cognitive impairment. About $77.9 \%$ people had moderate physical activity, $10.5 \%$ people had heavy physical activity, and $4.2 \%$ people had low physical activity. These ChiSquare analysis indicated significance value was 0.000 (less than $\alpha=0,05$ ). The correlation between physical activity and cognitive function had a positive correlation. Conclusions: There was correlation between physical activity and cognitive function. Increase physical activity leads to bigher cognitive function score.
\end{abstract}

Key words: physical activity, cognitive function

\section{PENDAHULUAN}

Salah satu dampak dari perbaikan kualitas kesehatan dan kondisi sosial masyarakat adalah meningkatnya usia harapan hidup. Peningkatan usia harapan hidup tercermin dari semakin meningkatnya jumlah penduduk lanjut usia (lansia) dari tahun ke tahun. Berdasarkan hasil Sensus Penduduk 1971, jumlah penduduk lansia di Indonesia sekitar 5,31 juta orang. Seiring dengan kemajuan dalam pembangunan, jumlah tersebut meningkat pada tahun 2010 menjadi hampir 4 kali lipat, yaitu sekitar 18,04 juta orang atau 7,29 \% (Badan Pusat Statistik, 2010). Pada orang usia lanjut cenderung terjadi penurunan dari fungsi kognitif yang disebabkan oleh penyakit degeneratif ataupun karena proses penuaan (Pranarka, 2006). Fungsi kognitif merupakan dimensi penting dari kualitas hidup untuk lansia di semua negara. Hal ini erat kaitannya dengan kemampuan untuk memproses informasi dalam kehidupan sehari-hari dan membantu bentuk keseluruhan kesejahteraan selama hidup (Hu Y et al, 2011). Kemunduran fungsi kognitif dapat berupa mudah lupa (forgetfulness), gangguan kognitif ringan (Mild Cognitive Impairment / MCI), sampai ke demensia sebagai bentuk klinis yang paling berat (Wreksoatmodjo, 2012). 
Aktivitas fisik diidentifikasi merupakan salah satu faktor yang diduga ada hubungannya dengan fungsi kognitif. Beberapa studi melaporkan bahwa usia lanjut yang mengalami kesulitan melakukan pergerakan fisik atau tidak aktif, akan terjadi perbedaan dalam jumlah skor fungsi kognitifnya (Santoso T, 2011). Aktivitas fisik mempunyai pengaruh yang bermanfaat pada fungsi kognitif saat usia lanjut dan juga merupakan sebagai pencegahan terhadap gangguan fungsi kognitif dan demensia (Singh-Manoux et al, 2005). Suatu penelitian menyatakan bahwa aktivitas fisik dapat mencegah atau memperlambat onset dari penurunan fungsi kognitif atau demensia (Rockwood \& Middleton, 2007).

Menurut data Badan Pusat Statistik pada tahun 2011, jumlah lansia di Kota Malang berjumlah 68.509 jiwa. Kota Malang memiliki 5 kecamatan, salah satunya adalah Kecamatan Blimbing. Jumlah lansia di Kecamatan Blimbing merupakan yang terbanyak daripada kecamatan-kecamatan lainnya yang ada di kota Malang, yaitu sebesar 15.202 jiwa dan lansia yang berusia 60-69 tahun sebesar 9082 jiwa (Badan Pusat Statistik, 2011). Kecamatan Blimbing memiliki 11 kelurahan, salah satunya adalah Kelurahan Purwantoro. Kelurahan Purwantoro memiliki jumlah lansia terbanyak di antara kelurahankelurahan lainnya, yaitu sebesar 3609 jiwa dengan jumlah lansia terbanyak yang berusia 60-69 tahun di antara kelurahankelurahan lainnya, yaitu sebesar 2090 jiwa yang tersebar di 24 RW.

Tujuan penelitian ini adalah untuk mengetahui adanya hubungan antara aktivitas fisik dengan fungsi kognitif lansia pada lansia di Kelurahan Purwantoro Kecamatan Blimbing Kota Malang. Tujuan khusus dalam penelitian ini antara lain untuk mengetahui skor fungsi kognitif lansia berdasarkan usia di Kelurahan Purwantoro Kecamatan Blimbing Kota Malang, untuk mengetahui skor fungsi kognitif lansia berdasarkan pendidikan terakhir di Kelurahan Purwantoro Kecamatan Blimbing Kota Malang, dan untuk mengetahui skor fungsi kognitif lansia berdasarkan aktivitas fisik di Kelurahan Purwantoro Kecamatan Blimbing Kota Malang.

Manfaat klinis dalam penelitian ini adalah memberikan informasi pada kalangan medis tentang hubungan aktivitas fisik dengan fungsi kognitif lansia pada lansia usia 60-69 tahun di Kelurahan Purwantoro Kecamatan Blimbing Kota Malang. Manfaat akademik dalam penelitian ini adalah penelitian ini diharapkan dapat memberi masukan untuk penelitian lebih lanjut. Manfaat penelitian ini untuk masyarakat adalah sebagai tambahan informasi berkaitan dengan hubungan aktivitas fisik dengan fungsi kognitif lansia, sehingga dapat dilakukan upaya pencegahan terjadinya gangguan fungsi kognitif pada setiap lansia berdasarkan tingkat aktivitas fisiknya. Selain itu diharapkan masyarakat mengetahui bagaimana cara deteksi dini gangguan fungsi kogntif sehingga tidak jatuh dalam kondisi demensia.

\section{METODE}

Penelitian ini merupakan penelitian analitik observasional dengan pendekatan cross sectional. Penelitian dilakukan di Kelurahan Purwantoro Kecamatan Blimbing Kota Malang pada bulan Februari 2014. Populasi penelitian ini adalah lansia yang berusia 60-69 tahun di Kelurahan Purwantoro Kecamatan Blimbing Kota Malang. Sampel penelitian ini adalah lansia yang berusia 60-69 tahun di Kelurahan Purwantoro Kecamatan Blimbing Kota Malang yang memenuhi kriteria inklusi dan tidak termasuk kriteria eksklusi. Besar sampel (n) pada penelitian ini dihitung dengan formula slovin (Sevilla et al, 1992) :

$$
\begin{aligned}
& \mathrm{n}=\mathrm{N} /\left(1+\left(\mathrm{Nx} \mathrm{e}^{2}\right)\right) \\
& \mathrm{n}=2090 /(1+(2090 \times(0,102)) \\
& \mathrm{n}=95,43 \\
& \mathrm{n}=95
\end{aligned}
$$

Keterangan :

$\mathrm{n}=$ besar sampel

$\mathrm{N}=$ ukuran populasi

$\mathrm{e}=$ nilai kritis (batas ketilitian) yang diinginkan

Teknik pengambilan sampel lansia dalam penelitian ini adalah menggunakan metode consecutive sampling yaitu sampel yang memenuhi kriteria inklusi dimasukkan dalam penelitian hingga jumlah sampel yang diperlukan terpenuhi.

Kriteria inklusi dalam penelitian ini adalah lansia yang berusia 60-69 tahun di Kelurahan Purwantoro Kecamatan Blimbing Kota Malang, bersedia menjadi subjek penelitian, dan pendidikan minimal SD. Kriteria eksklusi dalam penelitian ini adalah penderita gangguan psikiatri, penderita diabetes mellitus, penderita hipertensi, penderita dengan riwayat stroke, penderita dengan riwayat penyakit jantung, peminum alcohol, penderita gangguan pendengaran dan komunikasi.

Variabel bebas dari penelitian ini adalah aktivitas fisik. Variabel tergantung dari penelitian ini adalah fungsi kognitif. Instrumen penelitian terdiri dari International Physical Activity Questionnaires (IPAQ) long forms untuk mengetahui aktivitas fisik pada sampel penelitian, lembar test Mini Mental State Examination (MMSE) untuk mengetahui status fungsi kognitif pada sampel, skala depresi geriatri (geriatric depression scale) untuk mengeksklusikan penderita dengan gangguan psikiatri atau depresi, sfigmomanometer untuk mengukur tekanan darah, tes gula darah sewaktu untuk mengukur gula darah. Data yang diperoleh dikumpulkan dalam bentuk tabel distribusi frekuensi. Analisis data pada penelitian ini menggunakan uji Chi-Square untuk mengetahui hubungan antara aktivitas fisik dengan fungsi kognitif.

\section{HASIL DAN PEMBAHASAN}

Berdasarkan penelitian yang sudah dilakukan pada 95 responden, diperoleh karakteristik data dasar yang meliputi usia, jenis kelamin, dan pendidikan terakhir responden.

Tabel 1. Karakteristik Data Dasar

\begin{tabular}{lcccccc}
\hline \multirow{2}{*}{ Data } & \multicolumn{5}{c}{ Skor Fungsi Koguitif } & \\
& Gangguan Kognisi & Tidak Gangguan & Total \\
& (Skor 0-23) & Kognisi (Skor 24-30) & \\
\cline { 2 - 7 } & $\mathrm{f}$ & $\%$ & $\mathrm{f}$ & $\%$ & $\mathrm{f}$ & $\%$ \\
\hline Tsia (tahun) & 4 & 4.2 & 59 & 62.1 & 63 & 66.3 \\
$60-64$ & 3 & 3.2 & 29 & 30.5 & 32 & 33.7
\end{tabular}




\begin{tabular}{lcccccc}
\hline Jenis Kelamin & & & & & & \\
Laki-Laki & 1 & 1.0 & 36 & 37.9 & 37 & 38.9 \\
Perempuan & 6 & 6.4 & 52 & 54,7 & 58 & 61.1 \\
\hline Pendidikan Terakhir & & & & & & \\
SD & 6 & 6.4 & 27 & 28.3 & 33 & 34.7 \\
SMP & 1 & 1.0 & 22 & 23.2 & 23 & 24.2 \\
SMA & 0 & 0 & 22 & 23.2 & 22 & 23.2 \\
D1 D2 D3 D4 Sarjana & 0 & 0 & 17 & 17.9 & 17 & 17.9
\end{tabular}

Berdasarkan tabel di atas dapat diketahui bahwa responden terbanyak pada rentang usia 60-64 tahun dengan jumlah 63 orang $(66,3 \%)$, kemudian diikuti rentang usia 65-69 tahun dengan jumlah 32 orang (33,7\%). Dari 7 orang yang mengalami gangguan kognitif dengan skor 17 hingga 23, sebanyak 4 orang $(4,2 \%)$ berusia 60 hingga 64 tahun dan 3 orang $(3,2 \%)$ berusia 65 hingga 69 tahun. Sedangkan 88 orang lainnya yang memiliki tidak gangguan kognitif dengan skor 24 hingga 30, sebanyak 59 orang (62,1\%) berusia antara 60 hingga 64 tahun dan 29 orang (30,5\%) berusia 65 hingga 69 tahun.

Jenis kelamin responden terbanyak adalah perempuan dengan jumlah 58 orang (61,1\%). Sedangkan jumlah responden dengan jenis kelamin laki-laki lebih rendah daripada perempuan, yaitu berjumlah 37 orang $(38,9 \%)$. Dari 7 orang yang mengalami gangguan kognitif dengan skor 17 hingga 23, sebanyak 1 orang $(1,0 \%)$ berjenis kelamin laki-laki dan 6 orang $(6,4 \%)$ berjenis kelamin perempuan. Sedangkan 88 orang lainnya yang tidak gangguan kognitif dengan skor 24 hingga 30, sebanyak 36 orang $(37,9 \%)$ berjenis kelamin laki-laki dan 52 orang $(54,7 \%)$ berjenis kelamin perempuan.

Pendidikan terakhir responden terbanyak adalah berpendidikan terakhir setingkat SD dengan jumlah 33 orang $(34,7 \%)$, kemudian diikuti 23 orang $(24,2 \%)$ berpendidikan terakhir setingkat SMP, 22 orang $(23,2 \%)$ berpendidikan terakhir setingkat SMA, dan 17 orang (17,9\%) berpendidikan setingkat diploma hingga sarjana. Dari 7 orang mengalami gangguan kognitif dengan skor kognitif 17 hingga 23, sebanyak 6 orang $(6,4 \%)$ berpendidikan terakhir setingkat SD dan 1 orang $(1,0 \%)$ berpendidikan terakhir setingkat SMP. Sedangkan pada 88 orang lainnya yang tidak gangguan kognitif dengan skor 24 hingga 30, sebanyak 27 orang $(28,3 \%)$ diantaranya berpendidikan terakhir setingkat SD, masing-masing 22 orang (23,2\%) berpendidikan terakhir setingkat SMP dan SMA, dan 17 orang $(17,9 \%)$ berpendidikan terakhir setingkat diploma hingga sarjana.

\section{Tabel 2. Distribusi Skor Fungsi Kognitif} Berdasarkan Aktivitas Fisik

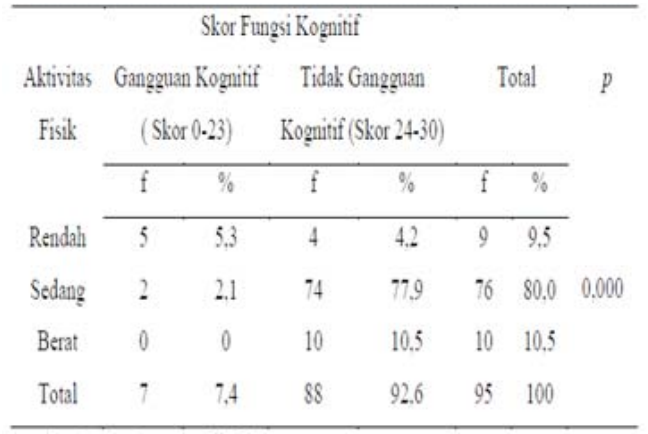

Berdasarkan tabel di atas diketahui bahwa dari 7 orang yang mengalami gangguan kognitif dengan skor kognitif 17 hingga 23, sebanyak 5 orang $(5,3 \%)$ memiliki aktivitas fisik rendah dan 2 orang $(2,1 \%)$ memiliki aktivitas fisik sedang. Sedangkan 88 orang lainnya yang tidak mengalami gangguan kognitif dengan skor kognitif 24 hingga 30, sebanyak 74 orang $(77,9 \%)$ memiliki aktivitas fisik sedang, 10 orang $(10,5 \%)$ memiliki aktivitas fisik berat, dan 4 orang $(4,2 \%)$ memiliki aktivitas fisik rendah.

Berdasarkan hasil analisis uji Chi-Square didapatkan nilai signifikansi sebesar 0,000 dimana nilai tersebut lebih kecil dari $\alpha=0,05$ sehingga dapat disimpulkan bahwa terdapat hubungan yang signifikan antara aktivitas fisik dengan fungsi kognitif. Hubungan antara aktivitas fisik dengan fungsi kognitif adalah positif, sehingga semakin tinggi aktivitas fisik, maka semakin tinggi pula skor fungsi kognitifnya.

Pada penelitian ini dapat diketahui bahwa dari 7 orang yang mengalami gangguan kognitif, sebanyak 4 orang $(4,2 \%)$ berusia 60 hingga 64 tahun dan 3 orang $(3,2 \%)$ berusia 65 hingga 69 tahun. Hal ini tidak sesuai dengan penelitian yang dilakukan oleh William dimana dalam penelitian tersebut disebutkan bahwa semakin bertambahnya usia merupakan faktor risiko mayor terjadinya penurunan fungsi kognitif pada lanjut usia karena otak mengalami perubahan dalam proses penuaan (William et al, 2010). Terdapat banyak teori proses penuaan, diantaranya karena radikal bebas. Radikal bebas dapat terbentuk di alam bebas dan di dalam tubuh jika fagosit pecah, dan sebagai produk sampingan di dalam rantai pernafasan di dalam mitokondria. Radikal bebas bersifat merusak karena sangat reaktif sehingga dapat bereaksi dengan DNA. Walaupun telah ada sistem penangkal radikal bebas dalam tubuh, namun sebagian radikal bebas tetap dapat lolos, bahkan semakin banyak radikal bebas terbentuk sehingga proses pengrusakan terus terjadi, kerusakan organel sel makin lama dan makin banyak dan akhirnya sel mati (Martono H, 2006). Radikal bebas juga dijumpai pada lingkungan misalnya pada asap rokok (Prakash et al, 2001).

Pada penelitian ini peneliti tidak meneliti merokok sebagai faktor risiko penurunan fungsi kognitif dimana asap rokok berperan sebagai radikal bebas yang dapat menyebakan perubahan dalam otak sejalan dengan proses penuaan. Tetapi berdasarkan pengamatan peneliti saat dilaksanakan penelitian, terdapat kecenderungan anggota keluarga responden yang merokok. Dari 7 orang yang mengalami gangguan kognitif, paling banyak yang mengalami gangguan kognitif adalah responden dengan berjenis kelamin perempuan yaitu sebanyak 6 orang $(6,4 \%)$. Walaupun sampel tidak merokok tetapi ada anggota keluarga yang merokok, hal tersebut juga bisa mempengaruhi fungsi kognitif pada sampel yang diteliti. Perokok pasif dapat menghirup partikel gas di dalam rokok sama dengan perokok aktif, tetapi partikel-partikel dalam asap tanpa filter yang melayang dari pembakaran ujung rokok yang lebih halus dan lebih terkonsentrasi dapat dihirup oleh perokok pasif dimana partikel-partikel tersebut dihirup lebih dalam ke paru-paru dan tinggal lebih lama dalam tubuh perokok pasif dibandingkan perokok aktif (Pershagen G, 1999).

Selain karena peneliti tidak meneliti merokok sebagai faktor risiko penurunan fungsi kognitif, pada penelitian ini 
tidak dapat menunjukkan bahwa semakin bertambahnya usia maka semakin berisiko terjadinya gangguan kognitif dikarenakan terdapat perbedaan jumlah sampel, yaitu jumlah sampel dengan usia 60-64 tahun lebih banyak dibandingkan sampel dengan usia 65-69 tahun.

Pada penelitian ini dapat diketahui bahwa dari 7 orang yang mengalami gangguan kognitif dengan skor 17-23, sebanyak 6 orang $(6,4 \%)$ diantaranya berpendidikan terakhir setingkat SD dan 1 orang $(1,0 \%)$ berpendidikan terakhir setingkat SMP. Sedangkan pada 88 orang lainnya tidak mengalami gangguan kognitif dengan skor kognitif antara 24 hingga 30, sebanyak 27 orang $(28,3 \%)$ diantaranya berpendidikan terakhir setingkat SD, masing-masing 22 orang $(23,2 \%)$ berpendidikan terakhir setingkat SMP dan SMA dan $17(17,9 \%)$ orang berpendidikan terakhir setingkat diploma hingga sarjana. Dapat disimpulkan bahwa semakin tinggi pendidikan, maka semakin tinggi pula skor fungsi kognitifnya. Hal ini sesuai dengan suatu teori synaptic reserve hypothesis, dimana orang yang berpendidikan tinggi mempunyai lebih banyak sinap di otak dibandingkan dengan orang yang berpendidikan rendah. Ketika sinap tersebut rusak karena ada proses penyakit Alzheimer, maka sinap yang lain akan menggantikan tempat yang rusak tadi. Teori ini berhubungan dengan cognitive reserve hypothesis dimana orang yang beredukasi memiliki lebih banyak sinap pada otak dan mampu melakukan kompensasi dengan baik terhadap hilangnya suatu kemampuan (Alen JS et al, 2005).

Dari 88 sampel yang tidak mengalami gangguan fungsi kognitif, jumlah paling banyak yang tidak mengalami gangguan kognisi adalah sampel dengan berpendidikan terakhir SD, yaitu berjumlah 27 orang $(30,7 \%)$. Hal ini bisa disebabkan karena sampel tersebut melakukan aktivitas fisik yang sedang hingga berat sehingga memiliki skor fungsi kognitif yang tinggi. Selain itu, ada beberapa hal yang dapat meningkatkan fungsi kognitif yang tidak diteliti oleh peneliti, seperti makanan. Makanan yang mengandung antioksidan berfungsi memperlambat atau mencegah terjadinya proses menua akibat radikal bebas, terutama di otak yang dapat menghambat gangguan kognitif (Kusnidar \& Mitri, 2003).

Pada penelitian ini dapat diketahui bahwa terdapat kecenderungan peningkatan aktivitas fisik dengan peningkatan fungsi kognitif. Dapat dilihat dari jumlah sampel yang mengalami gangguan fungsi kognitif sebanyak 7 orang, 5 orang $(5,3 \%)$ diantaranya memiliki aktivitas fisik rendah. Sedangkan dari jumlah sampel yang tidak mengalami gangguan kognitif sebanyak 88 orang, 74 orang $(77,9 \%)$ diantaranya memiliki aktivitas fisik yang sedangdan 10 orang lainnya $(10,5 \%)$ memiliki aktivitas fisik yang berat. Hal tersebut menunjukkan bahwa aktivitas fisik yang rendah merupakan salah satu faktor risiko terjadinya gangguan kognitif dan begitu juga sebaliknya, orang yang memiliki aktivitas fisik sedang hingga berat akan cenderung tidak memiliki gangguan kognitif.

Hal tersebut sesuai dengan penelitian yang dilakukan di Swedia terhadap 331 lansia yang sehat. Penelitian tersebut menunjukkan bahwa semakin tinggi aktivitas fisik yang dilakukan, maka fungsi kognitif akan semakin baik. Level dari aktivitas fisik berhubungan positif dengan volume otak, volume white matter, dan volume gray matter (Benedict $C$ et al, 2012). Aktivitas fisik dapat meningkatkan neurogenesis dan faktor neurotrofik brain derived neurotropic factor (BDNF) yang dapat meningkatkan ketahanan dan pertumbuhan beberapa tipe dari neuron, meliputi neuron glutamanergik. Brain derived neurotropic factor (BDNF) berperan sebagai mediator utama dari efikasi sinaptik, penghubung sel saraf, dan plastisitas sel saraf. Secara signifikan, efek in iterjadi di hipokampus, yaitu suatu wilayah otak dimana tempat pusat belajar dan memori. Aktivitas fisik dapat meningkatkan vaskularisasi otak dan berkontribusi memelihara fungsi kognitif selama penuaan (Cotman et al, 2002).

Pada sampel yang mengalami gangguan fungsi kognitif sebanyak 7 orang, sebanyak 2 orang (2,1\%) memiliki aktivitas fisik sedang dikarenakan dalam penelitian ini peneliti tidak meneliti faktor-faktor lain yang dapat mempengaruhi fungsi kognitif, seperti obesitas, kolesterol, dan merokok (Wreksoatmodjo BR, 2014).

Pada sampel yang tidak mengalami gangguan kognitif sebanyak 88 orang, terdapat 4 orang $(4,2 \%)$ memiliki aktivitas fisik yang rendah dikarenakan pada penelitian ini peneliti tidak meneliti faktor-faktor lain yang dapat meningkatkan fungsi kognitif selain aktivitas fisik, seperti makanan. Makanan yang mengandung vitamin B, E, C, beta karoten, chromium, selenium, kalsium, zinc, dan magnesium dapat berperan sebagai antioksidan di dalam tubuh. Antioksidan tersebut berfungsi memperlambat atau mencegah terjadinya proses menua akibat radikal bebas, terutama di otak yang dapat menghambat gangguan kognitif (Kusnidar \& Mitri, 2003).

Pada penelitian ini dianalisis dengan uji Chi-Square untuk mengetahui hubungan antara aktivitas fisik dengan fungsi kognitif. Terbukti bahwa ada hubungan yang signifikan antara aktivitas fisik dengan fungsi kognitif dengan nilai signifikansinya $=0,000$ yang lebih kecil dari $\alpha=0,05$. Hubungan antara aktivitas fisik dengan fungsi kognitif adalah hubungan yang positif, sehingga semakin tinggi aktivitas fisik yang dilakukan, maka semakin tinggi pula skor fungsi kognitifnya.

\section{SIMPULAN}

Terdapat hubungan antara aktivitas fisik dengan fungsi kognitif lansia pada lansia usia 60-69 tahun di Kelurahan Purwantoro Kecamatan Blimbing Kota Malang. Semakin tinggi aktivitas fisik, maka akan semakin tinggi pula skor fungsi kognitifnya. Didapatkan skor fungsi kognitif pada lansia dengan skor 0-23 (gangguan kognitif), sebanyak 4,2\% berusia 60-64 tahun dan sebanyak 3,2\% berusia 65-69 tahun. Sedangkan yang memiliki skor 24-30 (tidak gangguan kognitif), sebanyak $62,1 \%$ berusia $60-64$ tahun dan 30,5\% berusia $65-$ 69 tahun. Didapatkan skor fungsi kognitif pada lansia dengan skor 0-23 (gangguan kognitif), sebanyak 6,4\% berpendidikan terakhir setingkat SD dan sebanyak 1,0\% berpendidikan terakhir setingkat SMP. Sedangkan yang memiliki skor 24-30 (tidak gangguan kognitif), sebanyak $28,3 \%$ berpendidikan terakhir setingkat SD, masing-masing $23,2 \%$ berpendidikan terakhir setingkat SMP dan SMA serta sebanyak 17,9\% berpendidikan terahir setingkat diploma hingga sarjana. Didapatkan skor fungsi kognitif pada lansia dengan skor 023 (gangguan kognitif), sebanyak 5,3\% memiliki aktivitas fisik rendah dan sebanyak 2,1\% memiliki aktivitas fisik sedang. Sedangkan yang memiliki skor 24-30 (tidak gangguan kognitif), 
sebanyak 77,9\% memiliki aktivitas fisik sedang, 10,5\% memiliki aktivitas fisik berat, dan 4,2\% memiliki aktivitas fisik rendah.

\section{DAFTAR PUSTAKA}

Allen JS, Bruss J, Damasio H, 2005, The Aging Brain: The Cognitive Reserve Hypothesis and Hominid Evolution, Am J Hum Biol, 17(6), pp. 673-689.

Badan Pusat Statistik, 2010, Statistik Penduduk Lanjut Usia Indonesia 2010, Badan Pusat Statistik, Jakarta, pp. 10.

Badan Pusat Statistik Kota Malang, 2011, Malang dalam Angka 2011, Badan Pusat Statistik, Malang, pp. 27.

Benedict C, Brooks SJ, Kullberg J, Nordenskjöld R, Burgos J, 2012, Association between Physical Activity and Brain Health in Older Adults, Neurobiology of Aging, pp, 18.

Benjamin C, 2010, Essentials of Human Anatomy and Physiology, Pearson Education, United States.

Centers for Disease Control (CDC), 2010, State Indicator Report on Physical Activity, Department of Health and Human Services, Atlanta, U.S.

Cotman C, Berchtold N, 2002, Exercise: A Behavioral Interventions to Enhance Brain Health and Plasticity, TRENDS in Neurosciences, 25(6), pp. 295-300.

Dharmaperwira-Prins, Reni, 2004, Hemisfer Serebri, Dalam: Dharma Y (ed), Gangguan-Gangguan Komunikasi Hemisfer Kanan dan Pemeriksaan Komunikasi Hemisfer Kanan (PKHK), Djambatan, Jakarta, pp.10-11.

Decarli C, 2003, Mild Cognitive Impairment: Prevalence, Prognosis, Etiology and Treatment, The Lancet Neurology, 2, pp. 15-21.

Dumping CE, Siste, 2006, Deteksi Dini Gangguan Fungsi Kognitif pada Populasi Lanjut Usia dalam Kumpulan Makalah Pelatihan Pengelolaan Gangguan Fungsi Kognitif pada Populasi Lanjut Usia, Bagian Psikiatri FK UI, Jakarta.

Erlangga WS, 2010, Subjective Well-Being pada Lansia Penghuni Pati Jompo, viewed 11 Februari 2013. < http://repository. gunadarma.ac.id/bitstream/123456789/1050/1/ 10504164.pdf>.

Estes MEZ, 2002, Mental Status and Neurological Treatment, In: Long Edition, Delmar, United States, pp. 620.

Etgen T, Sander D, Huntgeburth U, Poppert H, Forstl H, Bickel H, 2010, Physical Activity and Incident Cognitive Impairment in Elderly Persons, Arch Intern Med, 170 (2), pp. 186-192.

Folstein MF, Folstein SE, McHugh PR, 1975, Mini-Mental State: A Practical Method for Grading the Cognitive State of Patients for the Clinician,J Psychiatr Res, 12, pp. 189198.

Foster PP, Rosenblatt KP, Kuljiš RO, 2011, Exercise Induced Cognitive Plasticity, Implications For Mild Cognitive Impairment and Alzheimer's Disease, Frontiers In Neurology Dementia, 2(28), pp: 1-10.

Geda Y et al, 2010, Physical Exercise, Aging, and Mild Cognitive Impairment, Arch Neurol, 67(1), pp. 80-86.

Hernandez S, Coelho F, Gobbi S, Stella F, 2009, Effects of Physical Activity on Cognitive Functions, Balance, and Risk of Falls in Elderly Patients with Alzheimer's Dementia, Rev Bras Fisioter, 14(1), pp. 68-74.
Hesti, Harris S, Mayza A, Prihartono J, 2008, Pengaruh Gangguan Kognitif terhadap Gangguan Keseimbangan Pada Lanjut Usia, 25(3), pp. 26-31.

Hu Y, Lei X, Smith JP, Zhao Y, 2011, Effects of Social Activities on Cognitive Functions, RAND Labor and Population Working Paper, WR-918, viewed 11 Februari 2013, <www.rand.org/content/.../RAND_ WR918.pdf $>$

International Physical Activity Questionnaire (IPAQ), 2005, Guidelines for Data Processing and Analysis of the International Physical Activity Questionnaire, http://www.ipaq. ki.se/scoring.pdf.

Kadir A, 2007, Olahraga Pada Usia Lanjut (Lansia), Wijaya Kusuma, I, pp. 63-68.

Kaplan H, Saddock B, Grebb J, 2010, Demensia, Dalam: Wiguna IM (ed), Sinopsis Psikiatri Ilmu Pengetahuan Perilaku Psikiatri Klinis, Bina Rupa Aksara, Tangerang, pp: 529-533.

Kowalski K, Rhodes R, Naylor P, Tuokko H, MacDonald S, 2012, Direct and Indirect Measurement of Physical Activity in Older Adults: A Systematic Review of the Literature, International Journal of Behavioral Nutrition and Physical Activity, 9, pp. 8.

Kumar R, Looi JCL, Raphael B, 2009, Type 2 Diabetes Mellitus, Cognition, and Brain in Aging: A Brief Review, Indian J Psychiatry, 51, pp. 35-38.

Kusnindar A, Mitri R, 2003, Mencegah Penyakit Degeneratif dengan Makanan, Majalah Cermin Dunia Kedokteran, 140, pp. 41-47.

Lamsudin R, 1999, Demensia Vaskuler: Tinjauan Aspek Serebrovaskuler-Patologi, Kriteria, Diagnosis, Epidemiologi, Faktor Risiko, Pencegahan dan Pengobatan, Berkala Neuro Sains, 1 (1), pp. 1-10.

Lezak MD, 1995, Classes of Cognitive Function, In: Howieson DB (ed), Neuropsychological Assessment $3^{\text {rd }}$ ed, Oxford University, New York, pp. 25-29.

Lumbantobing SM, 2006, Kecerdasan Usia Lanjut dan Demensia, BP FKUI, Jakarta, pp. 1-43.

Lumbantobing SM, 2006, Status Mental, Dalam: Utama H (ed), Neurologi Klinik Pemeriksaan Fisik dan Mental, BP FKUI, Jakarta, pp. 153-184.

Markam S, 2003, Pembagian Daerah Otak Fungsional Menurut Luria, Dalam: Soemarno M (ed), Pengantar Neuropsikologi, BP FKUI, Jakarta, pp. 48-51.

Martono H, 2006, Teori Proses menua, Dalam: Darmojo RB (ed), Geriatri (Ilmu Kesehatan Usia Lanjut), Balai Penerbit FK UI, pp. 8-9.

Maryam S, Ekasari MF, Rosidawati, Jubaedi A, Batubara I, 2008, Klasifikasi Lansia, Dalam: Angriani R (ed), Mengenal Usia Lanjut dan Perawatannya, Salemba Medika, Jakarta, pp: 33.

Myers J, 2008, Factors Associated with Changing Cognitive Function in Older Adults: Implications for Nursing Rehabilitation, Rehabilitation Nursing, 33(3), pp. 117-122.

Pershagen G, 1999, Accumulating Evidence on Health Hazards of Passive Smoking, Acta Paediatr, 88 (5), pp. 490.

Prakash A, Rigelhof F, Miller E, 2001, Antioxidant Activity, Medalliaon Laboratories Analitycal Progress, 10, pp. 1.

Pezzotti P, Scalmana S, Mastromattei A, Lallo D, 2008, The Accurancy of the MMSE in Detecting Cognitive Impairment When Administered by General Practicioners: $A$ 
Prospective Observational Study, BMC Family Practice, 9, pp. 29.

Pranarka K, 2006, Penerapan Geriatrik Kedokteran Menuju Usia Lanjut yang Sehat, Universa Medicina, 25, pp. 187-197.

Purwadi T, 2002, Manajemen Penderita Mild Cognitive Impairment (MCI). Simposium Demensia, Pertemuan Ilmiah Nasional Neurogeriatri Pertama, Jakarta, pp.7-14.

Qomariyati A, 2013, Hubungan Kecemasan dan Aktivitas Fisik dengan Kehidupan Seksual pada Wanita Menopause di Kelurahan Sajen Wilayah Kerja Puskesmas Trucuki I Kabupaten Klaten, Jurnal Kesehatan Masyarakat, 2, pp. 5.

Reed SK, 2011, Tahapan Pemrosesan Informasi, Dalam: Oktafiani R (ed), Kognisi Terapi dan Aplikasi Edisi 7, Salemba Humanika, Jakarta, pp. 9.

Rockwood K, Middleton L, 2007, Physical Activity and The Maintenance of Cognitive Function, Alzhemers Dement, 3, pp. 38-44.

Rosmalina Y, Permaesih D, 2008, Aktivitas Fisik dan Penggunaan Energi Pekerja Laki-Laki, Gizi Indon, 31 (2), pp. 98-106.

Santoso T, Shofia A, 2011, Gangguan Gerak dan Fungsi Kognitif pada Wanita Lanjut Usia, Jurnal Kesehatan, 4, pp. 41-57.

Sari E, 1993, Sampling Design, Dalam: Mandasari D (ed), Audience Research, Andi Offset, Yogyakarta, pp. 55-56.

Sastroasmoro S, 2011, Studi Cross Sectional, Dalam: Ghazali VM, Sastromihardjo S, Soedjarwo SR, Soelaryo T, Pramulyo HS (ed), Dasar-Dasar Metode Penelitian Klinis, Sagung Seto, Jakarta, pp. 97.

Satyanegara, 2010, Anatomi Susunan Saraf Pusat, Dalam: Hasan RY, Abubakar S, Maulana AJ, Sufarnap E, Benhadi I, Mulyadi S (ed), Ilmu Bedah Saraf Edisi IV, Gramedia Pustaka Utama, Jakarta, pp. 19-2.1

Sevilla C, Ochave J, Punsalan T, Regala B, Uriarte G, 1992, Research Method, Rex Printing Company, Quezon, pp. 187-188.

Singh-Manoux A, Hillsdon M, Brunne E, Marmot M, 2005, Effects of Physical Activity on Cognitive Functioning in Middle Age: $\quad$ Evidence From theWhitehall II Prospective Cohort Study, Am J Public Health, 95, pp. 2252-2258.

Suryadi, 2004, Hubungan Antara Tingkat Gangguan Kognitif dengan Stadium Retinopati Diabetika pada Diabetes Mellitus Tipe 2, Masters Thesis, Diponegoro University.

Tjahyanto A, Surilena, 2009, Penatalaksanaan NonFarmakologis Demensia, Majalah Kedokteran Damianus, 8, pp. 7-10.

Weuve J, Kang JH, Manson JE, Breteler MMB, Ware JH, Grodstein F et al, 2004, Physical Activity, Including Walking and Cognitive Function in Older Woman, JAMA, 292 (12), pp. 1454-1461.

Williams K, Kemper S, 2010, Exploring Interventions to Reduce Cognitive Decline in Aging,J Psychosoc Nurs Ment Health, 48(5), pp. 42-51.

Wiyoto, 2002, Gangguan Fungsi Kognitif Pada Stroke in Pendidikan Kedokteran Berkelanjutan Ilmu Penyakit Saraf, FK UNAIR, Surabaya, pp. 1- 31.
World Health Organization (WHO), 2010, Global Recommendations on Physical Activity for Health, Available from: http://whqlibdoc.who.int/publications / 2010 / 9789241599979_eng.pdf

Wreksoatmodjo BR, 2012, Penelitian Pendahuluan atas Hubungan Social Engagement dengan Fungsi Kognitif, Cermin Dunia Kedokteran, 39, pp. 110-117. Wreksoatmodjo BR, 2014, Beberapa Kondisi Fisik dan Penyakit yang Merupakan Faktor Risiko Gangguan Fungsi Kognitif, Cermin Dunia Kedokteran, 41(1), pp. 25-32.

Yuniati F, Riza M, 2004, Faktor-Faktor yang Berhubungan dengan Kesulitan Mengingat dan Konsentrasi Pada Usia Lanjut di Indonesia Tahun 2004, Jurnal Pembangunan Manusia, 2, pp. 9-25.

Zuhir E, 2011, Hubungan Gangguan Fungsi Kognitif dengan Hipertensi Ditinjau dari Aspek IL-6 dan TNFAlfa, Neurologist Thesis, Andalas University. 